\title{
NOTES
}

\section{WHITMAN AND THE COMMONWEALTH}

In December of 1862 Walt Whitman rushed from Brooklyn to Washington, D.C. to render aid to his wounded brother George who was serving as a First Lieutenant in the Fifty-first New York Volunteers at the time. ${ }^{1}$ As it turned out, George's wound was not serious. However, Walt was so touched by the abject needs of the multitude of wounded and dying Union soldiers who crowded the hospitals in Washington that he decided to stay on in the capital rendering what assistance he could to these unfortunate wretches. $\mathrm{He}$ also began to search for a full-time position which would support his existence there.

Despite letters from Ralph Waldo Emerson introducing Walt to some of the most powerful men in Washington, it would be two years before he would finally secure a clerkship in the Interior Department. Nevertheless, throughout this period, he would continue his ministry to the sick and dying. In January, 1863, he was appointed a "Delegate of the Christian Commission." His duties included "distributing stores where needed, in hospitals and camps; circulating good reading materials amongst soldiers and sailors; visiting the sick and wounded, to instruct, comfort, and cheer them, and aid them in correspondence with their friends at home; [and] aiding Surgeons on the battlefield and elsewhere in the care and conveyance of the wounded to hospitals."2

Lacking full-time employment, Walt soon found it necessary to appeal to friends and relatives for funds to support his charitable endeavors. In addition to these personal appeals, in February of 1863 he published two articles in the New York Times describing his efforts to serve the needs of the wounded soldiers for whom he cared. This effort resulted in additional contributions. $\mathrm{He}$ also wrote to friends in the Boston area and they too sent contributions. ${ }^{3}$ One of the Boston friends to whom Whitman appealed directly was James Redpath. Whitman undoubtedly first met Redpath when he was in Boston in the spring of 1860 to arrange for the first regular publication of Leaves of Grass. Whitman's publishers, Thayer and Eldridge, were committed abolitionists and their offices served as a gathering place for like-minded reformers. Thayer notes in his autobiography that:

The new fighting abolitionists in Boston formed a little society in the back part of our store where we had concealed, but ready for use, pistols and ammunition, knives and bludgeons. Our members wore around the neck under the collar a narrow black ribbon as a distinguishing mark. We knew each other as "Black Strings.",4

During the relatively short life of their publishing house, Thayer and Eldridge dedicated themselves almost exclusively to the publication of antislavery works, which included Redpath's The Life of Fohn Brown (1860) and Echoes of Harper's Ferry (1860), the latter containing one of Emerson's John Brown addresses. In 
light of this fact it may seem somewhat odd that Thayer and Eldridge should be interested in publishing a purely literary work like Leaves of Grass. However, the obvious unorthodoxy of Whitman's work may have been appealing. As Jerome Loving has observed, Thayer and Eldridge were "pulsating with transcendental teachings and abolitionist propaganda [and were] determined to find books that advocated a departure from traditional attitudes toward humanity." 5

Whitman also met other prominent abolitionists at this time, including John Townsend Trowbridge, poet and abolitionist novelist, and William Douglas O'Connor, whose abolition novel Harrington was also being published by Thayer \& Eldridge. ${ }^{6}$ Additionally, during his stay in Boston Whitman would meet and befriend one of Emerson's more prominent Concord neighbors, Franklin Benjamin Sanborn. Like the others, Sanborn was also a fervent abolitionist. As secretary of the Massachusetts "Kansas Committee" Sanborn developed a close relationship with John Brown. As a member of a group of Brown supporters known as the "Secret Six" he may have had advance notice of Brown's abortive raid on the federal arsenal at Harper's Ferry. In the spring of 1860, following Brown's execution for treason, Sanborn was arrested and ordered to appear before the Mason Committee of the United States Senate which was investigating Brown's associates. He refused to cooperate and was eventually released on the grounds that the federal agents who arrested him had no jurisdiction in Massachusetts. During this difficult time Sanborn was grateful for the support that was shown to him by friends and associates, and also, as it turns out, by at least one prominent stranger. In his own account of his hearing Sanborn notes, "I sat in the Old Court House listening to the arguments, and as I sat there saw an extraordinary man sitting near the door, wearing a carpenter's jacket, grey or blue-a very striking looking person. . . . A few days later, I was in Boston, and went round to the publishing office of Thayer \& Eldridge, and there sitting on the counter was this extraordinary person I had seen in the Courthouse. I was introduced to him. He was Walt Whitman. My personal acquaintance began at that time."7 As it turns out, these friendships with Boston's radical abolitionists would prove to be among Whitman's most enduring, especially in times of need.

In what appears to be a draft of his letter to Redpath, Whitman described some of the details of his hospital service and added, "I wish you would ask any body you know who is likely to contribute-It is a good holy cause, surely nothing nobler-I desire you if possible could raise for me, forthwith, for application to these wounded \& sick here, (they are from Massachusetts \& all the New England states, there is not a day but I am with some Yankee boys, \& doing some trifle for them) - a sum -if possible $\$ 50-$ if not, then less $-\$ 30-$ or indeed any am't.$- " 8$ Redpath later reported that he had called Whitman's appeal to the attention of Emerson, who promised to do what he could. Undoubtedly Redpath also shared Walt's communication with his other abolitionist friends in Boston. One of them, Sanborn, was editing the Commonwealth at this time.

The Commonwealth was established in 1862 as an antislavery journal which advocated immediate emancipation. Its first editor was Moncure Daniel Conway, a prominent Unitarian abolitionist and friend to Emerson, Thoreau, and other transcendental luminaries. In his autobiography Conway notes that 
the "Commonwealth was recognized as a sort of organ of the Commonwealth of Massachusetts in its relation to the national crisis." $\mathrm{He}$ also observes that the paper "paid attention to literature, and several young writers made their debuts in our paper." Indeed, judging from its contents, the paper was one of Boston's most literate and literary. In addition to political reporting on antislavery matters, every issue of the Commonwealth carried poetry, fiction, book reviews, literary notices, and even literary gossip. During the Civil War period the paper carried the first publication of Louisa May Alcott's Hospital Sketches, works by Bronson Alcott, Emerson, Thoreau, Henry Ward Beecher, William Ellery Channing, David Wasson, and others.

In 1863 Conway travelled to England to campaign there for the Union cause, and Sanborn took over editorship of the paper, a position which he would hold throughout the duration of the war. ${ }^{10}$ In this position Sanborn did not forget his old friend. He had been following closely Whitman's hospital experiences and had collected and personally contributed funds for this cause. ${ }^{11}$ In light of all this it is probably not surprising that on April 10, 1863, the Commonwealth ran a short article which not only praised Whitman personally for his generous and noble services to the sick and dying in Washington's army hospitals, but also suggested that he should be installed permanently in this position at government cost. The complete article reads as follows:

One of the most beloved and tender hearted of the visitors at the hospitals at Washington is Walt Whitman author of Leaves of Grass. However his "barbaric yap" may sound over other roofs, it sends sweet music into the sick wards at the Capital. A gentleman who accompanied him on several of his visits, relates that his coming was greeted by the soldiers with unvarying pleasure, and that he soothed the homesick boys so often seen there, with a tenderness that no woman could excel. His friends say that he cured one or two young soldiers who were dying of homesickness by his sympathy and loving kindness. Dying of homesickness is no figure of speech, but a reality of weekly occurrence in our army. To such invalids the religious tract, or the mechanical consolation of theology, give no relief; not musty manna from the Church wilderness, but living waters of sympathy from the warm heart of a man who loves them is what they need to save them. And this they get from the rough singer of Brooklyn. Walt, like other poets, is not excessively rich, and therefore may not stay in Washington much longer; but as long as he can afford to remain he means to keep at his self-elected and unpaid post, doing good to the sick and wounded. What a pity that when so many thousands of dollars are spent, to but little purpose for this work, that a hundred or two could not be devoted to retain this efficient volunteer.

Unfortunately for Whitman the notice did not bring about the desired results. In early May Redpath reported that Emerson "tried to have something done about you, but failed." He then goes on to note that "there is a prejudice agst you here among the 'fine' ladies \& gentlemen of the transcendental School. It is believed that you are not ashamed of your reproductive organs, and, somehow, it wd seem to be the result of their logic-that eunuchs only are fit for nurses. If you are ready to qualify yourself for their sympathy \& support, that you may not unnecessarily suffer therefrom, is, the sincere wish of your friend."12

Despite the fact that Whitman would continue to suffer the prejudices of certain Boston bluenoses, his relationship with Boston's radical abolitionist clique would continue to pay dividends. While in England Conway openly 
promoted Whitman and his work and helped to bring Leaves of Grass to the attention of British readers and critics alike. ${ }^{13}$ Also, when Walt was fired from his position in the Interior Department by Secretary Harlan, the Commonwealth ran an editorial in its February 3, 1866, issue titled "Secretary Harlan Playing Cato the Censor," which condemned the Secretary's actions. Three weeks later Sanborn published a long and positive critique of Drum-Taps in Commonwealth. Gay Wilson Allen suggests that Sanborn undoubtedly had a particular interest in the subject matter of Drum-Taps because of his earlier knowledge of Whitman's extensive hospital work. ${ }^{14}$ Obviously, for some at least, this gentle lover of suffering humanity would always hold a special place in their hearts.

University of Scranton

LEN Gougeon

\section{NOTES}

1 Gay Wilson Allen, The Solitary Singer: A Critical Biography of Walt Whitman (New York: Macmillan, 1955), 281-283.

2 Justin Kaplan, Walt Whitman, A Life (New York: Bantam, 1980), 275.

3 Allen, 290.

4 Quoted in Florence Bernstein Freedman, William Douglas O'Connor: Walt Whitman's Chosen Knight (Athens: University of Ohio Press, 1985), 101.

5 Jerome Loving, Walt Whitman's Champion: William Douglas O'Connor (College Station: Texas A\&M University Press, 1978), 35.

6 See Allen, 240, and Kaplan, 254-255.

7 Franklin Sanborn, "Whitman and Emerson," in Transcendental and Literary New England, ed. Kenneth Walter Cameron (Hartford: Transcendental Books, 1975), 202203.

8 The Correspondence, ed. Edwin Haviland Miller (New York: New York University Press, 1961), 1:122-123.

9 Autobiography, Memories and Experiences of Moncure Daniel Conway (Boston: Houghton, Mifflin, 1904), 1:369.

10 Franklin Sanborn, Recollections of Seventy Years (Boston: Gorham Press, 1909), 264-265.

11 Allen, 368.

12 Correspondence, 1:122-123n.

13 Correspondence, 1:14.

14 Allen, 368.

\section{WALT WHITMAN AND WILLIAM COWPER: A BORROWING}

On Walt Whitman's reading in British poetry Floyd Stovall observes that Whitman hardly cared for early or late neoclassical poets. Citing a passage from 